\title{
Agronomic and molecular characterization of gamma ray induced banana (Musa sp.) mutants using a multivariate statistical algorithm
}

\author{
Rosa Karla Nogueira Pestanana $\cdot$ Edson Perito Amorim • \\ Cláudia Fortes Ferreira • Vanusia Batista de Oliveira Amorim • \\ Larissa Santos Oliveira • Carlos Alberto da Silva Ledo • \\ Sebastião de Oliveira e Silva
}

Received: 12 August 2010/Accepted: 13 December 2010/Published online: 4 February 2011

(C) Springer Science+Business Media B.V. 2011

\begin{abstract}
Bananas are tropical fruits grown worldwide playing a key role in market trade and especially used as main food source for low income populations. In Brazil, bananas are mainly consumed in natura, occupying the second largest internal market. Nevertheless, this crop presents low availability of productive commercial varieties with good agronomic characteristics. A strategy undertaken to solve this problem is the development of new cultivars through conventional genetic breeding methods. However, this strategy presents some obstacles such as female sterility and low number of seeds. In order to overcome these shortcomings, use of mutation induction aiming the selection of mutants with desirable agronomic characteristics seems to have great potential for developing new cultivars. The objective of the present work was to evaluate the genetic variability in putative banana 'Pacovan' (AAB genome, subgroup Prata Type) mutants submitted to gamma ray irradiation,
\end{abstract}

R. K. N. Pestanana · L. S. Oliveira

Universidade Federal do Recôncavo da Bahia, Campus

Universitário, Cruz das Almas, BA 44380-000, Brazil

E. P. Amorim $(\bowtie) \cdot$ C. F. Ferreira $(\square)$.

V. B. de Oliveira Amorim - C. A. da Silva Ledo .

S. de Oliveira e Silva

Embrapa Mandioca e Fruticultura, Rua Embrapa S/N C.P.

007, Cruz das Almas, BA 44380-000, Brazil

e-mail: edson@cnpmf.embrapa.br

C. F. Ferreira

e-mail: claudiaf@cnpmf.embrapa.br using a set of agronomical and molecular data (ISSR markers). The distance between the putative 'Pacovan' mutants varied from 0.26 to 0.64 with cophenetic correlation coefficient of 0.7669 . Four mutants were selected based on best agronomical characteristics and height. This data also shows that there is variability that can be explored after the irradiation of 'Pacovan' banana mutants, which can be used in the genetic breeding program of banana aiming to develop short new varieties that also present good agronomic characteristics. This is the first attempt to use combined data in order to evaluate the genetic variability in putative banana mutants.

Keywords In vitro mutagenesis - ISSR markers . Multivariate analysis $\cdot$ Musa $\mathrm{sp}$

\section{Introduction}

Bananas are grown in more than 120 tropical and subtropical countries, mainly by small farmers. According to FAO (http://faostat.fao.org/) (FAO 2010), in 2008, the total area harvested and total production was approximately 5 million hectares and 82 tons, respectively. These numbers demonstrate the importance of bananas as a strong commodity, playing key economic and social roles in many developing countries, being considered as staple food for millions of people worldwide. 
In Brazil, bananas are the second fruit consumed in natura, after citrus (Silva and Torres Filho 1997). Although bananas play a key economic and social role in the Country, there is low availability of productive commercial varieties presenting short height and disease resistance. Therefore, a strategy to overcome this problem is the development of new cultivars through conventional genetic breeding. However, due to many obstacles encountered in the conventional breeding of bananas, such as female sterility and low number of seed production, the use of induced mutation aiming the selection of mutants with desirable agronomic characteristics poses as a plausible approach for the development of new cultivars.

The study of genetic diversity is very important in breeding programs especially in elucidating the genetic variability available to breeders. Molecular markers have been used to determine the genetic diversity in many species (Guasmi et al. 2008; Qian et al. 2001; Joshi et al. 2000; Gaudeul et al. 2000). These markers, especially those based on PCR (Polymerase Chain Reaction) methods, including AFLP (Restriction Fragment Length Polymorphism), RAPD (Random Amplified Polymorphic DNA), microssatélites or SSRs (Simple Sequence Repeats) and ISSR (Inter-Simple Sequence Repeats), have been broadly used to estimate genetic diversity, genetic stability and phylogenetic studies in bananas (Mattos et al. 2010a, b; Opara et al. 2010; El-Khishin et al. 2009; Miri et al. 2009; Lakshmanan and Venkataramareddy 2007; Ning et al. 2007; Amorim et al. 2008, 2009a, b, Creste et al. 2004).

Nowadays, here are very few institutions worldwide that actually carry out crosses in their banana breeding programs, such as Embrapa-Brazilian Company of Agriculture and Livestock research (Brazil), CIRAD-Agricultural Research for Development (Guadalupe), FHIA-Fundacion Hondureña de Investigacion Agricola (Honduras), IITA-International Institute of Tropical Agriculture (Nigeria), CARBAP-African Center for Bananas and Plantain Research (Camaroon), TNAU-Tamilnadu Agricultural University, NRCB-National Research Centre for Banana, and BRS-Banana Research Station (India). These breeding programs rely heavily on the knowledge of the diversity available in banana germplasm banks and molecular markers are therefore important tools to help access this diversity.
Conventional breeding programs aiming to obtain new varieties short in height can be very time consuming and many times frustrating. One way to speed up the obtainment of short varieties is through gamma ray irradiation induction and subsequent evaluation of the genetic diversity present in the irradiated material. Therefore, the objective of the present work is to select short 'Pacovan' putative mutants submitted to gamma ray irradiation and estimate the genetic diversity using agronomic and ISSR molecular marker data via multivariate statistical algorithms.

\section{Materials and methods}

\section{Plant material}

Healthy in vitro banana plants from the Pacovan (AAB) cultivar, a Prata type cultivar much used in Brazil, with approximately $5 \mathrm{~cm}$ in length and 4-5 leaf primordia, supplied by the Campo Biotecnologia Vegetal Ltda. Company from Cruz das Almas, Bahia, were used for the induction of mutation aiming the selection of short plants. The Pacovan banana plants used originated from the field at Embrapa and their meristems used.

In vitro gamma ray induction of buds

Approximately 200 in vitro buds of the Pacovan banana cultivar were irradiated at the Centro de Energia Nuclear na Agricultura (CENA), from the University of São Paulo (USP), using $\mathrm{Co}^{60}$. The dose used was $20 \mathrm{~Gy}$ with rates of $1.322 \mathrm{kGy} \mathrm{h}^{-1}$. This dose was selected from a sensitivity test conducted by Resende (2005), which indicated 20 Gy for Pacovan (AAB) and $30 \mathrm{~Gy}$ for Pacovan Ken (AAAB). For each cultivar, ten buds were used as controls which also were sent to CENA/USP, but without exposure to $\mathrm{Co}^{60}$.

The irradiated buds were transferred to basic MS medium, solidified with $2.2 \mathrm{~g} \mathrm{l}^{-1}$ Phytagel, supplemented with $30 \mathrm{~g}$ of sucrose, $3.0 \mathrm{mg} \mathrm{l}^{-1}$ 6-bezilaminopurine (BAP), pH 5.8 and maintained in the growth chamber with controlled temperature of $27 \pm 2{ }^{\circ} \mathrm{C}$ and $16 \mathrm{~h}$ of light photoperiod. Plants were submitted to subcultures of 30 day intervals. 
After four subcultures, plants were rooted in MS medium supplemented with $0.25 \mathrm{mg} \mathrm{l}^{-1}$ of naphthalene acetic acid (NAA) and $8 \mathrm{~g} \mathrm{l}^{-1}$ of agar with $\mathrm{pH}$ adjusted to 5.8 and taken to the growth chamber with $16 \mathrm{~h}$ photoperiod and light intensity of $40 \mu \mathrm{mol} \mathrm{m} \mathrm{m}^{-2} \mathrm{~s}^{-1}$ and $26 \pm 2{ }^{\circ} \mathrm{C}$ where they remained for 35-30 days.

Approximately 1200 irradiated rooted plants and 600 rooted control plants were taken to a screen house where they were acclimatized in plastic tubes containing Plantmax (composed of processed wooden peels, expanded vermiculite, granulated charcoal, processed turf supplemented with macro and micronutrients) and in screen houses with 50\% sombrite, with light control and irrigation by automatic mist.

A pre-selection was carried out at the screen house using the selection criteria of plants with height inferior to the control in at least $10 \%$. Only these plants were evaluated in the field during two production cycles. From this selection, 179 irradiated 'Pacovan' plants, along with 36 controls were characterized agronomically.

\section{Agronomic characterization of mutants}

The experiment was implemented without any statistical design whereas each plant was considered a repetition. It was carried out at the experimental field at Embrapa Mandioca e Fruticultura located in Cruz das AlmasBahia, Brazil. Spacings were $3 \mathrm{~m} \times 4 \mathrm{~m}$ and plants fertilized according to technical recommendations.

Initially, 179 'Pacovan' irradiated plants and 36 controls were evaluated in two production cycles as to the following agronomic characteristics: number of days from flowering until harvest period; pseudostem diameter $(\mathrm{cm})$; plant height $(\mathrm{m})$; number of live leaves and suckers at flowering; bunch and hand weight $(\mathrm{kg})$ and average weight of fruits $(\mathrm{g})$; number of fruits per bunch; length of fruit in the second hand $(\mathrm{cm})$ and of the penultimate hand $(\mathrm{cm})$; diameter of the fruit in the second hand ( $\mathrm{mm})$ and of the penultimate hand $(\mathrm{mm})$; number of hands and live leaves during harvest; length $(\mathrm{cm})$ and diameter of the peduncle $(\mathrm{cm})$; presence of yellow Sigatoka during flowering and at harvest; color of the pseudostem of the midrib, of the border of the petiole and color of shoots; shape of the roseta; opening at the base of the petiole and position of leaves.
Selection of short mutants—agronomical data

Initially, an individual classification of plants in the population was carried out for the characteristics considered important in the selection of banana genotypes with short height, early flowering period and heavier bunches. Data obtained for these characteristics were organized in increasing order (for plant height and number of days until bunch emission) and decreasing order (for bunch weight) obtaining the classification number of each plant.

Afterwards, the classification number of each plant was multiplied by the 'weight' corresponding to each characteristic. For plant height a weight of 6 was given for being considered the most relevant characteristic in this study and 2 for number of days from planting to flowering and weight of bunch. At the end of this process the final punctuation of each plant was obtained using the following formula: $y=[0.6 \times$ (height classification $)+0.2 \times$ (classification of bunch emission $)+$ $0.2 \times$ (classification of bunch weight)]. At the end of the production cycle, the final punctuation was ordered in increasing order, obtaining the final classification. The selected plants were those present in the $10 \%$ best classified plants at the end of the production cycle.

Seventy-five putative Pacovan mutants were sampled. Sampling was carried out at the end of the first cycle choosing plants which presented short height and good bunches as the criteria (Fig. 1).

\section{DNA extraction and PCR conditions}

Genomic DNA was extracted from young leaves of the 75 putative 'Pacovan' mutants and 5 controls, non irradiated plants, using the CTAB method (Doyle and Doyle 1990). The quantity and quality of the DNA was carried out by comparative analysis of the samples on $0.8 \%$ agarose gels stained with ethydium bromide, the samples diluted in ultrapure water, and the concentration adjusted to $10 \mathrm{ng} \mu \mathrm{l}^{-1}$.

For the amplification via ISSRs the samples had a final volume of $15 \mu \mathrm{l}$, containing: $50 \mathrm{mM} \mathrm{KCl}, 10 \mathrm{mM}$ Tris- $\mathrm{HCl}(\mathrm{pH} 8,3), 1.5 \mathrm{mM} \mathrm{MgCl} 2,100 \mu \mathrm{M}$ of each dNTPs (dATP, dTTP, dGTP, dCTP), $0.4 \mu \mathrm{M}$ of each primer, $20 \mathrm{ng}$ of genomic DNA and one Unit of Taq DNA polymerase (Pharmacia Biotech, EUA).

Amplifications were carried out in the Perkin Elmer 9700 model thermocycler with the following 
Fig. 1 Plants chosen based on short height in comparison to the average height of the control plants

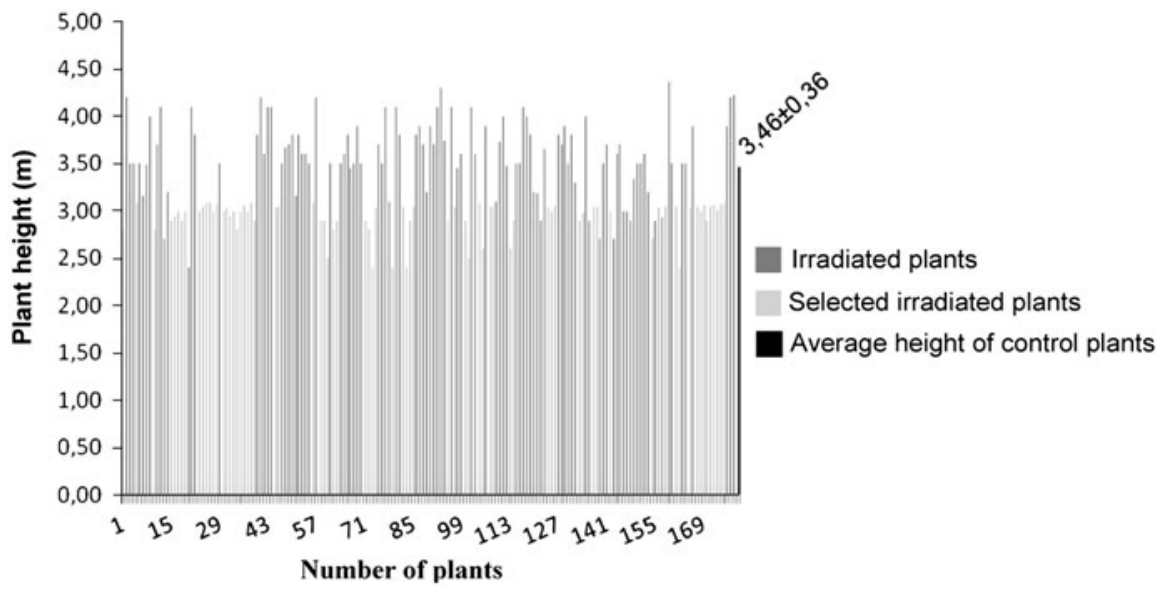

amplification steps: $94^{\circ} \mathrm{C}$ for $4 \mathrm{~min}$ followed by 35 cycles of $94^{\circ} \mathrm{C}$ for $40 \mathrm{~s}$, (annealing temperature of $48^{\circ} \mathrm{C}$ ) for $40 \mathrm{~s}, 72^{\circ} \mathrm{C}$ for $1 \mathrm{~min}$., with final extension of $72^{\circ} \mathrm{C}$ for $2 \mathrm{~min}$. The amplification products were separated by $2 \%$ gel eletrophoresis. Information regarding the ISSR primer sequences, annealing temperature (Ta) and total number of bands (TNB) are shown on Table 1.

\section{Statistical analysis of combined data}

Morphoagronomical and molecular data were submitted to the Ward-MLM statistical algorithm (Franco et al. 1998) using CLUSTER and MLM procedure in the SAS program (SAS Institute 2001), considering a total of six multicategoric characteristics (color of pseudostem, CPS; color of mid-rib, CMR; shape of roseta, SR; shape of roseta, SR; shoot color, SC; opening of the base of the petiole, OBP; color of petiole border, CPB and position of leaves, PL), 21 quantitative characteristics (number of days from planting until flowering, NDPF; number of days from planting until harvest, NDPH; number of days from flowering until harvest, NDFH; diameter of pseudostem, DPS $(\mathrm{cm})$; plant height, PH $(\mathrm{m})$; number of leaves until flowering, NLF; number of suckers, NS; bunch weight, BW (Kg), hand weight, $\mathrm{HW}(\mathrm{Kg})$; number of fruits, NF; average weight of fruit, AWF $(\mathrm{g})$; length of fruit of the second hand, LFSH $(\mathrm{cm})$; length of fruit of penultimate hand, LFPH $(\mathrm{cm})$; diameter of the fruit of the second hand ( $\mathrm{mm})$; diameter of fruit of next to the penultimate hand, DFPH (mm); number of hands, $\mathrm{NH}$; number of live leaves at harvest, NLLH; length of peduncle, LE $(\mathrm{cm})$,
Table 1 ISSR primers used in the amplification of 'Pacovan' banana mutants with their respective sequences, annealing temperatures $\left(T_{\mathrm{a}}\right)$ and total number of bands (TNB)

\begin{tabular}{|c|c|c|c|}
\hline Primer & Sequence & $T_{\mathrm{a}}$ & TNB \\
\hline $\mathrm{DiGA}^{\prime} \mathrm{C}$ & (GA)8C & 48 & 12 \\
\hline $\mathrm{DiGA3}^{\prime} \mathrm{RC}$ & $(\mathrm{GA}) 8 \mathrm{RC}$ & 48 & 12 \\
\hline TriGTA3'RC & (GTA)5RC & 48 & 12 \\
\hline $\mathrm{DiGT}^{\prime} \mathrm{RG}$ & (GT)8RG & 48 & 6 \\
\hline TriTAG3'RC & (TAG)5RC & 48 & 12 \\
\hline TriTGG3'RC & (TGG)5RC & 48 & 11 \\
\hline TriCTC $3^{\prime} \mathrm{RC}$ & (CTC)5RC & 48 & 8 \\
\hline TriGAT3'RC & (GAT)5RC & 48 & 9 \\
\hline TriAGA3'RC & (AGA)5RC & 48 & 10 \\
\hline 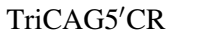 & $\mathrm{CR}(\mathrm{CAG}) 5$ & 48 & 10 \\
\hline 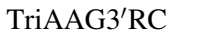 & (AAG)5RC & 48 & 15 \\
\hline TriTGA3'RC & (TGA)5RC & 48 & 14 \\
\hline TriCAA3'RC & (CAA)5RC & 48 & 13 \\
\hline 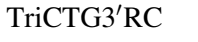 & (CTG)5RC & 48 & 11 \\
\hline TriTGC3'RC3 & (TGC)5RC & 48 & 06 \\
\hline TriGAG3'RC3 & (GAG)5RC & 48 & 05 \\
\hline TriTTC3'RC3 & (TTC)5RC & 48 & 05 \\
\hline DiGT3'A3 & $\mathrm{A}(\mathrm{GT}) 8$ & 48 & 05 \\
\hline DiGT5'CY3 & CY(GT)8 & 48 & 10 \\
\hline
\end{tabular}

diameter of peduncle $(\mathrm{cm})$; presence of yellow Sigatoka during flowering, PYSF; and presence of yellow Sigatoka during harvesting, PYSH, and 19 ISSR primers (186 polymorphic bands) in order to evaluate the genetic diversity. The amplified fragments were evaluated as present (1) and absent (0) bands. 
Cluster analysis was carried out by the UPGMA (Unweighted pair-group Method with arithmetic mean) method using the Mega-4.1 software (Tamaura et al. 2007), based on the distance matrix by the Gower algorithm (Gower 1971). The cophenetic correlation coefficient between the dissimilarity matrix and the cluster matrix was calculated using the GENES software (Cruz 2003). The ideal number of groups was defined according to the pseudo- $F$ and pseudo- $t^{2}$ criteria (SAS Institute 2001).

\section{Results and discussion}

Determining the genetic dissimilarity between individuals is an important and decisive point for clustering and analyzing diversity within and among populations (Kosman and Leonard 2005). The WardModified Location Model strategy was first proposed by Franco et al. (1998) and is a useful method for analyzing genetic divergence for genealogical comparison (Barbé et al. 2009) and selection of genotypes and accessions that best represent the entire population with the minimum loss of genetic diversity (Crossa and Franco 2004), however, there are not many reports in the literature.

The multicategoric and quantitative data for the second cycle of production was used. The possibility of combining multicategoric, quantitative and molecular data and being able to truly identify the number of clusters opens new perspectives in dissimilarity studies. In order to determine the correlation between the multicategoric, quantitative and binary data, a preliminary study was carried out calculating the correlation between two distance matrices; the distance matrix comprising of the multicategoric and quantitative data and the distance matrix calculated only for the binary data using the single simple coincidence indice. The correlation between these two matrices was $r=0.0199$, being very low and demonstrating that the data can be analyzed in a combined fashion, and that most of the variability observed could be attributed to genetic factors.

This is the first report of the use of the Ward-MLM method in bananas; however, this methodology has been used in other crops, such as snap beans (Barbé et al. 2009), Capsicum spp (Sudré et al. 2010), heirloom tomato (Gonçalvez et al. 2008) and kale
(Padilha et al. 2007). The use of the Gower algorithm showed to be very efficient in these studies.

The genetic variability of seventy-five putative 'Pacovan' mutants and 5 controls was analyzed using 21 quantitative, 6 multicategoric and 186 polymorphic bands originated from 19 ISSR markers using Ward-MLM algorithm (Fig. 2).

The distance between the putative 'Pacovan' mutants varied from 0.26 to 0.64 , with average distance of 0.459 and cophenetic correlation coefficient of $0.7669 * *$; value considered highly acceptable in these studies (Vaz Patto et al. 2004)). The closest putative 'Pacovan' mutants were PACOVAN 65 and PACOVAN 67, with 0.26 genetic distance and the most dissimilar were PACOVAN 26 and PACOVAN 2, with 0.64 . Results clearly show that there is variability among the putative 'Pacovan' mutants that can be explored and that this variability is mainly due to the effect of the gamma radiation since somaclonal variations from subcultivations normally do not lead to alterations in a great number of clones from the same genotype. Four putative 'Pacovan' mutants were selected among the $10 \%$ best classified as to the following characteristics evaluated at the end of the first production cycle: plant height, bunch weight and number of days from planting until flowering.

The height of the four plants selected among the 75 evaluated in the first production cycle was shorter than the average of the controls. The shortest height among the selected plants was for plant 40, with a difference of $0.56 \mathrm{~cm}$ in comparison to the controls (average height $=3.46 \mathrm{~m} \pm 0.36$ ). Furthermore, this mutant was the most precocious for inflorescence emission (44 days) and also was among those with greater bunch weight.

Bermudez et al. (2000), working with FHIA-21, observed in the first cycle, general frequency of variation of $4.78 \%$ whereas the most altered characteristics were plant height and number of fingers per bunch.

Regarding the number of days from planting to flowering, for the first cycle, plant 40 presented the smallest values when compared to the average of the controls and the irradiated clones. As for the number of days from planting to the harvest no variations were observed in the first cycle, with values close to the average of the controls.

Regarding bunch weight, the selected plants presented the highest values when compared with 
Fig. 2 Dendrogram constructed with 75 putative banana 'Pacovan' mutants and 5 controls using 21 quantitative, 6 multicategoric and 186 binary data (ISSR markers) by the Gower algorithm. The dendrogram was constructed using the UPGMA method and the MEGA-4 software package

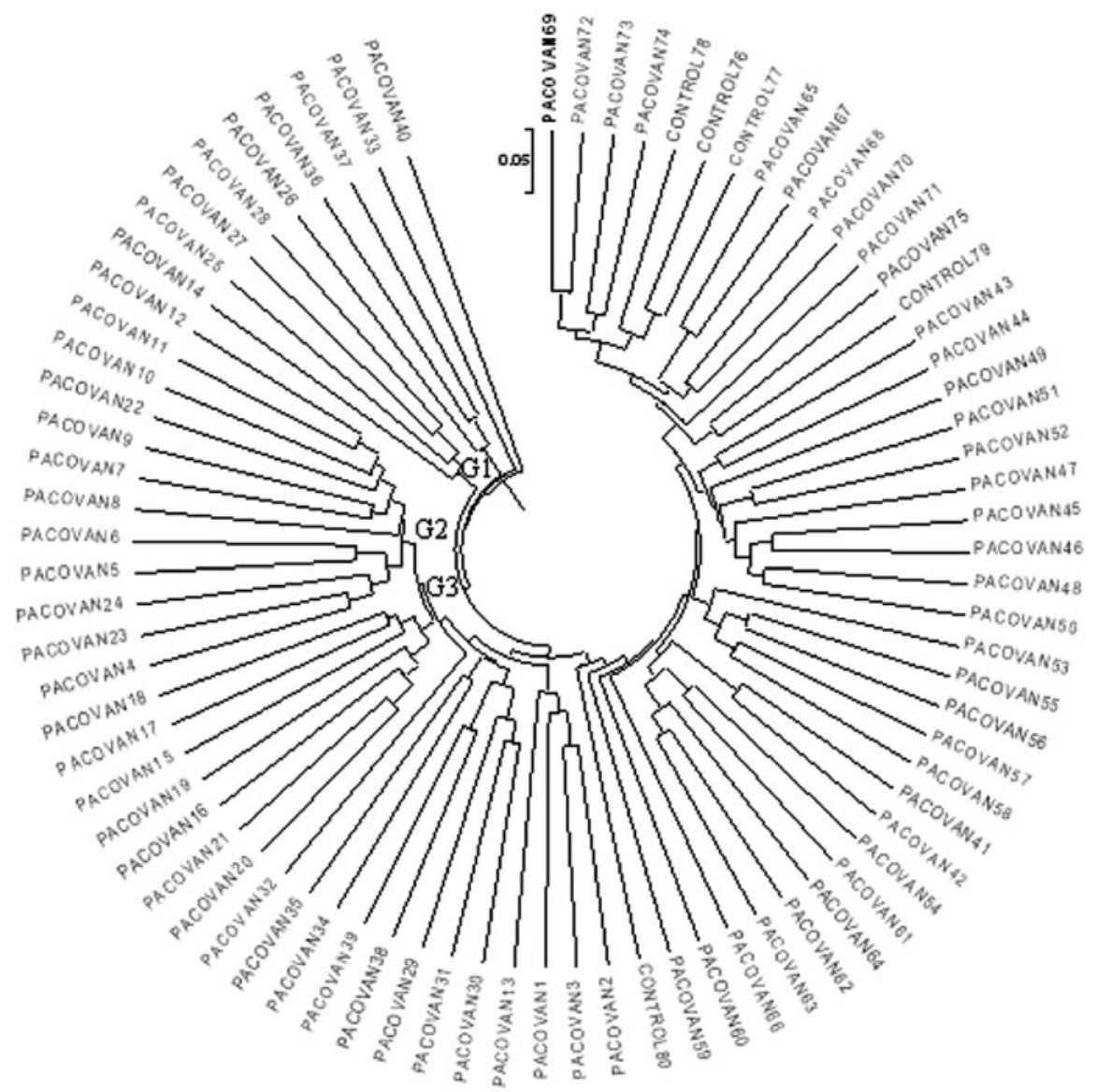

the controls and the average of the irradiated clones. For the weight of hands in the first cycle, the selected plants presented higher values and close to the average of the controls.

As for the average fruit weight, in the first cycle, plant 40 presented higher values among the observed in the selected plants, controls and in the average of the irradiated clones. In general, the four putative 'Pacovan' mutants selected were plants 28, 35, 38 and 40, taking plant height, bunch weight and number of days from planting until flowering, into consideration.

For the ISSR analysis with 19 primers for the irradiated 'Pacovan' a total of 186 polymorphic bands were obtained whereas 74 were monomorphic with an average of 9.8 total bands and 5.8 polymorphic bands, respectively. The largest number of bands was identified in primer TriAAG3 ${ }^{\prime} \mathrm{RC}$ ( 15 bands) and the smallest in primers $\operatorname{TriGAG}^{\prime} \mathrm{RC}$, TriTTC $^{\prime} \mathrm{RC}$ and DiGT3'A (5 bands).
Racharak and Eiadthong (2007) with a total of 36 ISSR primers in subspecies of Musa acuminata and cultivars with the A genome reported that 6 primers revealed a total of 128 bands. Works from Venkatachalam et al. (2007) using 50 RAPD primers and 12 ISSR primers, in the Nanjanagudu Rasabale banana cultivar, identified 625 bands. Results obtained by Ray et al. (2006) revealed a total of 5330 RAPD bands (21 primers) and 2741 ISSR bands (12 primers) for the Robusta (AAA) and Giant Governor (AAA) and Martaman (AAB) banana cultivars. The PSF test for the selection of the cut-off point of cluster formation is presented in Fig. 3.

The pseudo- $F$ and pseudo- $t^{2}$ criteria showed that the optimum number of groups is between 2 and 3 . Adopting the formation of three groups, with a drop from 9.407 to 2.660 points by the Ward-MLM cut-off value, it is shown that the smallest distance between the controls was 0.38 , with average distance between them of 0.33 . This small distance shows that the 


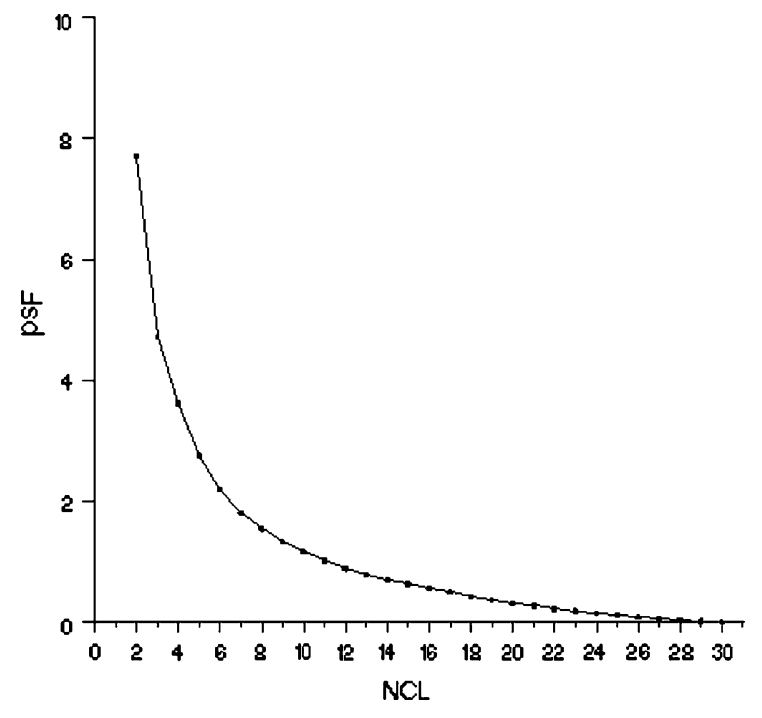

Fig. 3 Pseudo- $F$ and Pseudo- $t^{2}$ criteria with the optimum number of groups of $2-3$ using the Ward-MLM algorithmSAS software package (SAS Institute 2001)

controls are closely related (all placed in the G3 cluster) and therefore could serve as a good basis to be used in comparison to the irradiated material.

Regarding the four selected mutants, Pacovan 28 and 40 were placed in the same group (G1) and Pacovan 35 and 38 were placed in group G3. The use of combined data enables the study of genetic variability in a more reliable approach. The four mutants were selected based on best agronomical characteristics and height and are now undergoing field evaluations.

This data also shows that there is variability that can be explored after the irradiation of 'Pacovan' banana mutants, which can be used in the genetic breeding program of banana aiming to develop short new varieties that also present good agronomic characteristics. This is the first attempt to use combined data in order to evaluate the genetic variability in putative banana mutants.

\section{Conclusions}

The use of the Ward-MLM (Franco et al. 1998) combined data approach enabled the obtainment of reliable results regarding the genetic variability of irradiated 'Pacovan' bananas using gamma rays. These results show that there is genetic variability that can be used in the banana breeding program aiming the obtainment of short, precocious, high yield banana plants.

A combined analysis approach provides a better overview of the actual variability, whereas considering only the quantitative and/or qualitative data, the environmental influence could have a greater masking effect in the outcome of the analysis. This methodology provides a much better fit model to clustering analysis.

This is the first attempt to use the Ward-MLM multivariate statistical analysis in order to define the number of groups in the banana breeding program at Embrapa Mandioca e Fruticultura.

Acknowledgments The authors wish to thank the Conselho Nacional de Desenvolvimento Científico e Tecnológico (CNPq) for funding this project and also the Fundação de Amparo à Pesquisa do Estado da Bahia (FAPESB) for granting the scholarship of the first author.

\section{References}

Amorim EP, Reis RV, Santos-Serejo JA, Amorim VBO, Silva SO (2008) Variabilidade genética estimada entre diplóides de banana por meio de marcadores microssatélites. Pesquisa Agropecuária Brasileira 43(8):1045-1052

Amorim EP, Lessa LS, Ledo CAS, Amorim VBO, Reis RV, Santos-Serejo JA, Silva SO (2009a) Caracterização agronômica e molecular de genótipos diplóides melhorados de bananeira. Revista Brasileira de Fruticultura 31(1): 154-161

Amorim EP, Vilarinhos AD, Cohen KO, Amorim VBO, Santos-Serejo JA, Silva SO, Petana KN, Santos VJ, Paes NS, Monte DC, Reis RV (2009b) Genetic diversity of carotenoid-rich bananas evaluated by Diversity Arrays Technology (DArT). Genet Mol Biol 32(1):96-103

Barbé TC, Amaral-Júnior AT, Gonçalves LSA, Rodrigues R, Scapim CA (2009) Association between advanced generations and genealogy in inbred lines of snap bean by the Ward-Modified Location Model. Euphytica doi:10.1007/ s10681-009-0089-Z

Bermudez I, Orellana P, Pérez Ponce J, Clavelo J, Veitia N, Romero C, Mujica R, Garcia RL (2000) Improvement of the hybrid plantain clone FHIA-21 by mutagenesis in vitro. Infomusa 9(1):16-19

Creste S, Tulman-Neto A, Vencovsky R, Silva SO, Figueira A (2004) Genetic diversity of Musa diploid and triploid accessions from the Brazililan banana breeding program estimated by microsatellite markers. Genet Res Crop Evol 51:723-733

Crossa J, Franco J (2004) Statistical methods for classifying genotypes. Euphytica 137:19-37

Cruz CD (2003) Programa Genes, Versão Windows (2003.0.0). UFV, Viçosa, Brasil 
Silva J da, Torres Filho P Aspectos socioeconômicos (1997) In: A cultura da banana: aspectos técnicos, socioeconômicos e agroindustriais. Brasília: Embrapa-CNPMF 585

Doyle JJ, Doyle JL (1990) Isolation of plant DNA from fresh tissue. Focus 12(1):13-15

El-Khishin D, Belatus EL, El-Hamid AA, Radwan KH (2009) Molecular characterization of banana cultivars (Musa spp.) from Egypt using AFLP. Res J Agric Biol Sci 5(3): 271-279

FAO http://www.fao.org

Franco J, Crossa J, Villasenõr J, Taba S, Eberhart SA (1998) Classifying genetic resources by categorical and continuous variables. Crop Sci 38:1688-1696

Gaudeul M, Taberlet P, Bottraud-Till I (2000) Genetic diversity in an endangered alpine plant, Ryngium alpinum $\mathrm{L}$. (Apiaceae), inferred from amplified fragment length polymorphism markers. Mol Ecol 9:1625-1637

Gonçalvez LSA, Rodrigues R, Amaral-Júnior AT, Karasawa M, Sudré CP (2008) Comparison of multivariate statistical algorithms to cluster tomato heirloom accessions. Genet Mol Res 7(4):1289-1297

Gower JC (1971) A general coefficient of similarity and some of its properties. Biometrics 27:857-874

Guasmi F, Touil L, Féres K, Elfelah W, Triki T, Ferchichi A (2008) Genetic diversity of Tunisian barley accessions based on microsatellites markers. Biotechnology 7(4):781-786

Joshi SP, Gupta VS, Aggarwal RK, Ranjekar PK, Brar DS (2000) Genetic diversity and phylogenetic relationship as revealed by inter simple sequence repeat (IISR) polymorphism in the genus Oryza. Theor Appl Genet 100: 1311-1320

Kosman E, Leonard J (2005) Similarity coefficients for molecular markers in studies of genetic relationships between individuals for haploid, diploid and polyploidy species. Mol Ecol 14:415-424

Lakshmanan V, Venkataramareddy SR (2007) Molecular analysis of genetic stability in long-term micropropagated shoots of banana using RAPD and ISSR markers. Electron J Biotechnol 10(1):106-113, ISSN: 0717-3458

Mattos LA, Amorim EP, Amorim VBO, Cohen KO, Ledo CAS, Silva SO (2010a) Agronomical and molecular characterization of banana germplasm. Pesquisa Agropecuária Brasileira 45(2):146-154

Mattos LA, Amorim EP, Cohen KO, Amorim TB, Silva SO (2010b) Agronomical, physical and chemical characterization of banana fruits. Crop Breed Appl Biotechnol 10(3):225-231

Miri SM, Mousavi A, Naghavi MR, Talaei MAR, Khiabani BN (2009) Analysis of induced mutants of salinity resistant banana (Musa acuminata cv. Dwarf Cavendish) using morphological and molecular markers. Iran J Biotechnol 7(2):86-92

Ning S-P, Xu L-B, Lu y, Huang B-Z, Ge X-J (2007) Genome composition and genetic diversity of Musa germplasm from China revealed by PCR-RFLP and SSR markers. Scientia Horticult 114:281-288

Opara UL, Jacobson D, Al-Saady NA (2010) Analysis of genetic diversity in banana cultivars (Musa cvs.) from the south of Oman using AFLP markers and classification by phylogenetic, hierarchical clustering and principal components analyses. J Zhejang Univ Sci B 11(5):332-341

Padilha G, Cartea M, Ordás A (2007) Comparison of several clustering methods in grouping kale landraces. J Am Soc Horticult Sci 132:283-436

Qian W, Ge S, Hong DY (2001) Genetic variation within and among populations of a wild rice Oryza granulata from China detected by RAPD and ISSR markers. Theor Appl Genet 102:440-449

Racharak P, Eiadthong W (2007) Genetic relationship among subspecies of Musa acuminate Colla and A-genome consisting edible cultivated bananas assayed with ISSR markers. Songklanakarin J Sci Technol 29(6):1479-1489

Ray T, Dutta I, Saha P, Das S, Roy SC (2006) Genetic stability of three economically micropropagated banana (Musa spp.) cultivars of lower Indo-Gangetic plains, as assessed by RAPD and ISSR markers. Plant Cell Tissue Organ Cult 85(1):11-21

Resende JCF (2005) Melhoramento da bananeira (Musa spp.) utilizando indução de mutação com raios gama e variação somaclonal para a redução da altura de plantas. 2005, 155p. Tese (Doutorado em Energia Nuclear na Agricultura)-Centro de Energia Nuclear na Agricultura, Universidade de São Paulo, Piracicaba

SAS Institute Inc (2001) SASs user's guide: statistics. SAS Institute, Cary

Sudré CP, Gonçalves LSA, Rodrigues R, Amaral-Júnior AT, Riva-Souza EM, Bento CS (2010) Genetic variability in domesticated Capsicum spp as assessed by morphological and agronomic data in mixed statistical analysis. Genet Mol Res 9(1):283-294

Tamaura K, Dudley J, Nei M, Kumar S (2007) MEGA4: molecular evolutionary genetics analysis (MEGA) software version 4.0. Mol Biol Evol 24:1596-1599

Vaz Patto MC, Satovic Z, Pêgo S, Fevereiro P (2004) Assessing the genetic diversity of Portuguese maize germoplasm using microsatellite markers. Euphytica 137:63-67

Venkatachalam L, Sreedhar RV, Bhagyalakshmi N (2007) Genetic analysis of micropropagated and regenerated plantlets of banana as assessed by RAPD and ISSR markers. In Vitro Cell Dev Biol 43:267-274 